\title{
Prospects of Sweet Sorghum as a Raw Material for Ethanol Production
}

\author{
Ratnavathi $\mathrm{CV}^{*}$ \\ National Research Centre for Sorghum, India \\ Submission: September 18, 2017, Published: September 25, 2017 \\ *Corresponding author: Ratnavathi CV, National Research Centre for Sorghum, Rajendranagar, Hyderabad-500 030, India, \\ Email: ratnavathi@millets.res.in
}

\section{Introduction}

Sorghum crop is known for its efficient dry matter production among cereals. Sweet sorghum is a special type of sorghum that accumulates sugars (sucrose, glucose and fructose) in stalks, which form $70-80 \%$ of total biomass, apart from yielding considerable amount of grain. Sweet sorghum as a crop has wide adaptability, drought tolerance, and tolerant to water logging, saline alkali conditions, exhibits quick growth rate and rapid sugar accumulation. Being a $\mathrm{C}_{4}$ plant, sweet sorghum has a high photosynthetic potential producing 30-50 tons green cane along with 1.5-2.5tons grain/ha accumulating dry matter at a rate of $50 \mathrm{~g} / \mathrm{m}^{2} /$ day.

Of late there is an intensive search for suitable alternative feed stock to the existing sugarcane molasses for ethanol production, which has triggered due to the acute water shortages all over the country's sugarcane growing areas. Further, recent policy of the Government of India to blend 5\% ethanol in petrol has prompted all sugar industries to look for alternate feed stocks for making alcohol more economically and meet the need in case of shortage of molasses. Sweet sorghum, which is a crop close to sugarcane in respect of its sucrose accumulation and juicy nature of the stem, offers an excellent alternative feed stock apart from others such as sugarbeet. The advantage of sweet sorghum over sugarcane is that it is a four-month duration crop and can be raised through seed. The other advantage is that it can be grown with less inputs and water (maximum 2-3 irrigations) and even can be grown under rainfed conditions. The expected yield/recovery of ethanol (fuel grade) from sweet sorghum cane is 2000-2500 litres/ha (50 litres/ton). The by-product from sweet sorghum i.e its grain can also be utilized for ethanol production as currently sorghum grain is used for potable alcohol whose recovery is upto 400 litres per ton of grain. There is a good market for potable alcohol whose price is primarily decided by the molasses price. It is fluctuating and ranged between Rs. 1836 per litre during 2003-04. However, grain alcohol extraction technology is different from the stalk ethanol.

\section{Sweet Sorghum Varieties}

In addition to fuel alcohol production, Sweet sorghum can also be used for the production of jaggery, syrup and paper depending on the sucrose content and ratio between sucrose and reducing sugars content. Sweet sorghum research was started at NRCS in 1988 and many varieties and hybrids are being evaluated under the All India Coordinated Sorghum Improvement Programme (AICSIP). Two varieties were released so far, SSV 84 and HES 4, the former being the national release. Recently, a variety RSSV 9 from MPKV, Rahuri and a hybrid NSSH 104 from NRCS, Hyderabad were recommended for release. The sugar content varies from $16-23 \%$ brix and the fermentable sugars range from 15-21\%. Most of the sweet sorghum varieties mature between 115-125 days during the rainy season. Stalks can be harvested either along with grain or 4-5 weeks after the grain harvest. However, sweet sorghum varieties and hybrids bred under the national programme of AICSIP at NRCS have the capability to produce high biomass up to 45-50 tones/ha with juice brix between 18 and $22 \%$ and a grain yield of 1.5-2.5 tones/ha. NSS 209, NSS 216, NSS 218, NSS 219, RSSV 24, RSSV 46 and RSSV 59 are some of the promising genotypes identified from NATP breeding trial.

\section{Findings from Pilot Study for Ethanol Production}

A pilot study in collaboration with M/s Renuka Sugars in Munoli, Belgaum was conducted during 2002-03 for the production of ethanol (95\%) from sweet sorghum juice. This study was first of its kind in India. Two varieties sweet sorghum (SSV 74 \& SSV 84) and one hybrid (Madhura) were grown in more than 600 acres of dryland in farmer's fields. Nearly 125 hectares located in 66 villages (157 farmers) were covered with variety SSV 84 . The juice brix was $18 \%$ and about 112 tones of cane were used for one ferment or of capacity $60 \mathrm{KL}$. Fermentation was carried out for $48 \mathrm{hrs}$. The recovery of ethanol was approximately $9 \%$ of the juice and bagasse obtained was $46.44 \%$ with $2.58 \%$ sugars, which was successfully used 
for the cogeneration (2086 calories/tons). The fermentation of sugars was slow as the left over fermentation still contained sugars that contribute to $6.4 \%$ brix (Figure 1).

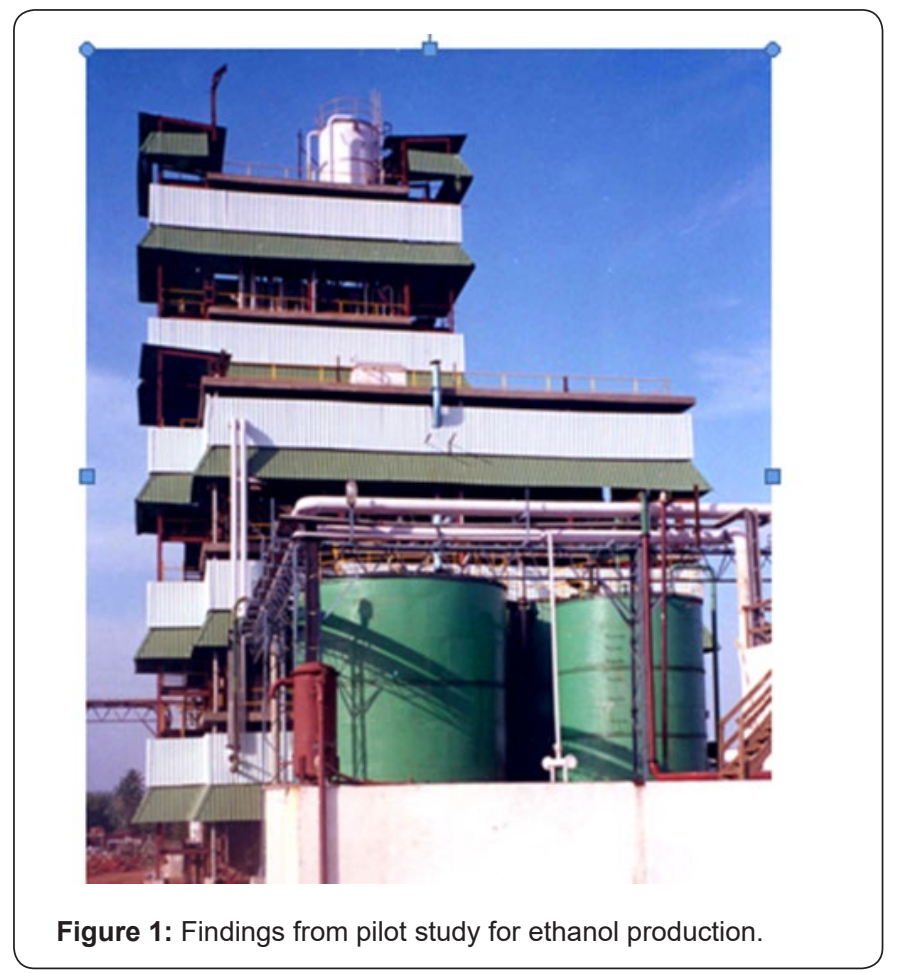

\section{Special Fermentation Strains for Sweet Sorghum}

The Yeast strain that is commonly used in distilleries does not efficiently ferment sweet sorghum juice sugars and the complete fermentation of sugars takes 72 hours. Strains that are more effective in terms of thermal tolerance and ethanol tolerance as compared to distillers strain were isolated and identified at NRCS. These are the non-pathogenic strains of and Candida tropicalis and Streptococcus pyogenes.

\section{Economic Feasibility of Sweet Sorghum for Ethanol Production}

From the economic feasibility study it is clear that the ethanol production from sweet sorghum offers a good alternative strategy that can supplement rather than a substitute the existing molasses based ethanol production from sugarcane. The cost of ethanol per litre from sugarcane molasses (at current price of molasses of Rs. 2000/ton) will be costlier by Rs.1.87/lt compared to that of sweet sorghum (Rs.13.41/lit). Further, the quality of rectified spirit obtained from sweet sorghum is of superior quality with good flavor/ odour as it is low in aldehydes and free from sulphates. The bagasse from sweet sorghum has a higher biological value than that of sugarcane when used as feed for animals with the available newer technologies and energy efficient industries.

\section{Competitiveness of Sweet Sorghum: Does it Compete With Sugarcane?}

The net income (at paid out costs) to the farmers from sweet sorghum cultivation accrue higher net returns (Rs.16625/ha) than sugarcane cultivation by Rs.1125/ha in the area of trials conducted by Praj industries, Pune while it is lower in sweet sorghum (Rs.16180/ha) than in sugarcane (Rs.22000/ha) in catchment area of Sagar sugars, Chittoor, which of course has to be ascertained by repeated field trials. However, interestingly the output-input ratio of sweet sorghum cultivation is higher than that of sugarcane in both the locations. In other words, the sweet sorghum cultivation yields higher returns per rupee invested and that too in a shorter period of just 4 months.

Apart from net returns, other issues do not straight away qualify sweet sorghum to compete with sugarcane molasses rather to complement with the latter from industry point of view The sugarcane industry is active for six months in a year and it is proposed that the existing machinery and operating system can optimally be used for sweet sorghum in the lean period of sugarcane crushing season, thereby generating employment and increased capacity utilization of sugar industries. Sweet sorghum can be grown successfully in June and February planting for maximum green cane yield and sugar content to ideally suit the lean periods of sugarcane.

Sugarcane is a long duration crop and highly demanding in terms of water and it can be grown only some areas with assured irrigation. In contrast sweet sorghum is highly adapted to a variety of growing environments.

\section{Options available for entrepreneurs}

While majority of the distilleries approached us are in favor of undertaking whole process from contact farming to ethanol marketing by them selves, few entrepreneurs expressed their interest in manufacturing intermediate product such as crude syrup concentrate from sweet sorghum juice using the available boilers which is equivalent to sugarcane molasses and selling to distilleries for ethanol preparation. The other possibility is hiring the closed down distilleries and other infra structure, machinery to manufacture rectified spirit ( $95 \%$ ethanol) and market to the user industries that make fuel ethanol (100\%).

\section{Seed production and distribution}

In the wake of high enthusiasm shown by sugar industries National Research Centre for Sorghum (NRCS) Rajendranagar, Hyderabad made attempts to produce breeder's seed of sweet sorghum variety SSV 84. The crop was raised in four hectares at Hyderabad during Rabi 2003-04 producing about 13.5 tons seed. The seed was distributed to different sugar industries in Andhra Pradesh, Tamil Nadu, Maharashtra, Karnataka and Orissa. Seed was sold at the rate of Rs.40/kg. M/s Sagar 
Sugars and Allied Products located at Chittoor District in Andhra Pradesh purchased the largest amount of seed (9 tons) followed by Godavari Sugars Private Limited (2.75 tons) located in Shakarwadi, Ahmednagar District of Maharashtra. The different branches of Sakthi Sugars located in Tamil Nadu and Orissa have purchased 1 to $\mathrm{n}$ seed.

Apart from this, NRCS has multiplied and produced seed under the seed village concept at Sankili, Srikakulam District, and Andhra Pradesh in collaboration with M/s GMR Sugar industry during the Rabi season of 2003-04 and produced 2.75 tons of seed. The farmers were given demonstration on raising the crop, as it is a non-traditional crop for that area (Figure 2).

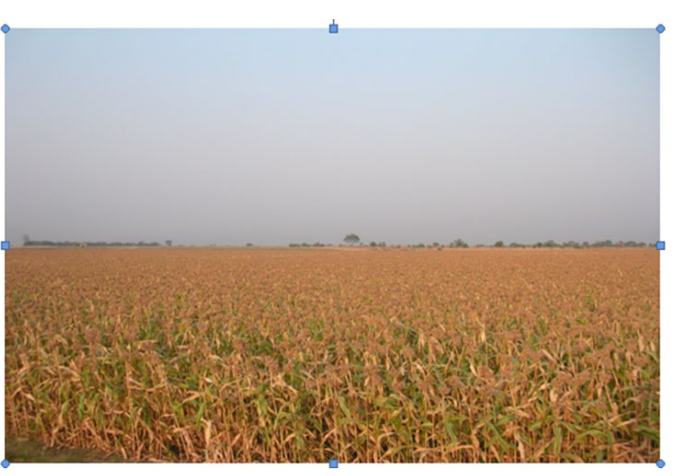

Figure 2: Seed production and distribution.

\section{Your next submission with Juniper Publishers} will reach you the below assets

- Quality Editorial service

- Swift Peer Review

- Reprints availability

- E-prints Service

- Manuscript Podcast for convenient understanding

- Global attainment for your research

- Manuscript accessibility in different formats ( Pdf, E-pub, Full Text, Audio)

- Unceasing customer service

Track the below URL for one-step submission https://juniperpublishers.com/online-submission.php 